\title{
Taphonomical interpretation of the Sima de los Huesos site (Atapuerca range, Burgos, Spain): a review
}

\author{
David RABADÀ I VIVES
}

Museu de Geologia del Seminari de Barcelona \& Departament d'Ensenyament de la Generalitat de Catalunya, C. València, 479, 08013 Barcelona, Spain; drabada@hotmail.com

Rabadà i Vives, D.M. 2015. Taphonomical interpretation of the Sima de los Huesos site (Atapuerca range, Burgos, Spain): a review. [Interpretación tafonómica del yacimiento de la Sima de los Huesos (Sierra de Atapuerca, Burgos, España): una revisión]. Spanish Journal of Palaeontology, 30 (1), 79-94.

\section{ABSTRACT}

The Sima de los Huesos site, Atapuerca, contains an important sample of fossilised human bones of Homo heidelbergensis. The nature of Sima de los Huesos ( $\mathrm{SH}$ ) human remains was interpreted as human burials but a bibliographic review of the literature published on this subject has given rise to a new perspective. According to this new revision $\mathrm{SH}$ site was originated by different taphonomical mechanisms. Competition between Homo and other predators for the cavity, accidental death around the pit and a feeding trough for felines and canines while the cave had other entrances nowadays obstructed, explain this human fossil association. Large felines fed on human remains around the pit. Canids and other scavengers came later for feeding. The water flows in the cave during heavy rainfall produced dispersion, mixing and abrasion in all these human skeletal remains. During all these processes a low sedimentation rate and eventual supply of corpses produced the observed fossil concentration. The majority of bears fell later by accident or died while hibernating near the site.

Keywords: Taphonomy, human burials, Homo heidelbergensis, Homo neanderthalensis, Sima de los Huesos, Atapuerca, Pleistocene.

\section{RESUMEN}

El yacimiento de la Sima de los Huesos en Atapuerca contiene una importante muestra de huesos humanos fosilizados de Homo heidelbergensis. La naturaleza de estos restos fue atribuida a un enterramiento humano, aunque una revisión bibliográfica de la literatura publicada sobre este tema ha proporcionado una nueva perspectiva. Según esta revisión el yacimiento fue originado por diferentes mecanismos tafonómicos. La competencia ecológica entre Homo y otros depredadores por la cavidad, muertes accidentales cercanas a la sima y un comedero de felinos y cánidos mientras la cavidad ostentaba otros accesos hoy desplomados, explican esta asociación fósil. Un gran felino se alimentó de los restos alrededor de la sima. Cánidos y otros carroñeros vinieron más tarde para alimentarse. Las corrientes de agua en la cueva durante episodios intensos de lluvia produjeron la dispersión, mezcla y abrasión en todos estos restos esqueléticos. Durante todos estos procesos una baja tasa de sedimentación más el aporte eventual de cadáveres propició la concentración fósil observada. Más tarde la mayoría de los osos cayeron por accidente o fallecieron mientras hibernaban cerca de la sima.

Palabras clave: Tafonomía, enterramientos humanos, Homo heidelbergensis, Homo neanderthalensis, Sima de los Huesos, Atapuerca, Pleistoceno. 


\section{INTRODUCTION}

The Sima de los Huesos site (SH) has yielded the largest accumulation of human remains from the Middle Pleistocene known to date. In the Sima de los Huesos site more than 6,500 human remains were found in only four cubic metres of sediments (Martínez et al., 2013) belonging to at least 28 individuals (Bermúdez de Castro et al., 2004). These fossils were attributed initially to archaic Homo sapiens (Arsuaga et al., 1993; Bermúdez de Castro et al., 1997) but later they were identified as Homo heidelbergensis (Pérez et al., 1999). In fact, the most appropriate name for Homo heidelbergensis is Homo neanderthalensis because some authors talk about a gradual succession of two different chronospecies, Homo heidelbergensis first and Homo neanderthalensis later (Bermúdez de Castro et al., 2004). This data implies that Homo heidelbergensis and Homo neanderthalensis are the same species. In addition, the high variability found in the Sima de los Huesos site (Arsuaga \& Martínez, 1999; Arsuaga et al., 2014) indicates beyond doubt that these human remains contain the old heidelbergensis chronospecies and Neanderthals too. Lately Chris Stringer has believed that the Sima de los Huesos site material belongs to the Neandertal clade, and perhaps represents a primitive form of Homo neanderthalensis (Stringer, 2012). Even so, the skeletal remains were described by their discoverers as belonging to the Neanderthal lineage (Arsuaga et al., 1993; Martínez \& Arsuaga, 1997) but they classified these human bones as Homo heidelbergensis for practical reasons (Arsuaga \& Martínez, 1999; Bermúdez de Castro et al., 2004). However, a recent study shows that the mitochondrial DNA of Sima de los Huesos hominin shares a common ancestor with Denisovan mtDNA rather than with "classic" Neandertal mtDNA (Meyer et al., 2014), which could be interpreted as the result of gene exchanges between the Neanderthal lineage and the Homo heidelbergensis with fertile descendants. Therefore these two species were the same. Finally Arsuaga et al. (2014) admit that these human remains belong to the preNeanderthal clade although to a new species perhaps.

In any case, the Sima de los Huesos site is renowned for its unique accumulation of human fossils (Arsuaga et al., 1993, 1997), which represents $80 \%$ of the global Middle Pleistocene fossil record for the genus Homo. Therefore the Sima de los Huesos site contains the highest concentration of primitive Homo around the world. Nowadays this concentration of human fossils has been explained as ritual burials by this primitive Homo who threw their dead relatives to the cave site as a symbolic act (Arsuaga, 1999; Arsuaga \& Martínez, 1999; Carbonell et al., 2003; Carbonell \& Mosquera, 2006). If this hypothesis were true we would be dealing with the first human funeral rite. This paper reviews the current taphonomical references about it.

\subsection{Geological setting}

The Sierra de Atapuerca is located in north central Spain, $14 \mathrm{~km}$ east of the city of Burgos (Fig. 1). The range is inside a northwest-southeast trending anticlinal of Upper Cretaceous limestone. This elevation stands around $100 \mathrm{~m}$ above the surrounding plain and 1,070 $\mathrm{m}$ over sea level. An extensive karstic system, Cueva Mayor, was developed inside this range at the same time as the peneplanation of the range during the Pliocene. This endokarstic system of the Sierra de Atapuerca comprises an extensive network of cavities, passages and galleries spanning more than $4.7 \mathrm{~km}$ (Ortega et al., 2013). The Sima de los Huesos site belongs to this karstic system and it is located at the south-west of Atapuerca range. Progressive fluvial incision allowed the cave system formation and humans could access to the interior through several entrances from $\sim 1.22 \mathrm{Myr}$ until the end of the Middle Pleistocene, when these cave entrances became filled and sealed. One of these cavities is the SH hominid-bearing deposit. On the other hand, the general features, cartography and the history of the Cueva Mayor system were described in detail by Arsuaga et al. (1997) and later by Ortega et al. (2013).

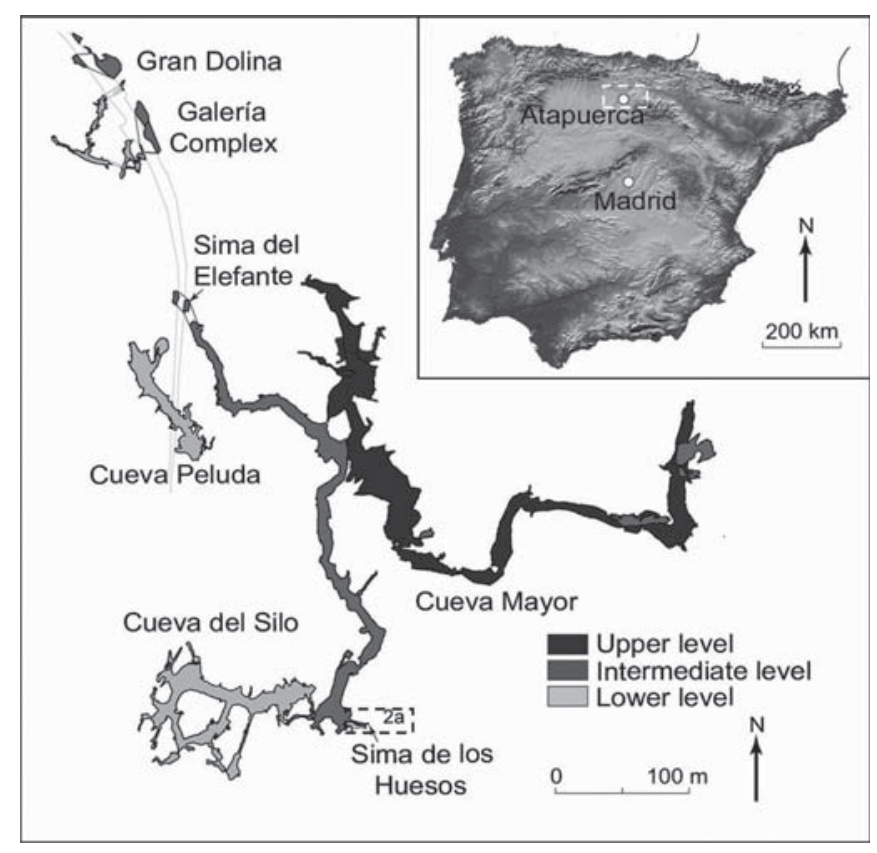

Figure 1. Atapuerca karst system with the location of the Sima de los Huesos site (Arnold et al., 2014, modified).

\subsection{The Sima de los Huesos site}

The modern access to the Sima de los Huesos site is via the Cueva Mayor entrance and 400 metres from it, Cyclops Gallery is reached and the vertical shaft that gives access 
to Sima de los Huesos (Arsuaga et al., 1997). This shaft has approximately $13 \mathrm{~m}$ deep, ending slightly below the top of a ramp. The fossil site is located at the bottom of this pit (Arsuaga et al., 1993, 1997; García \& Arsuaga, 2011; Arnold et al., 2014) (Fig. 2). Sima de los Huesos excavation area consists of two connected areas at the bottom of this shaft, the Rampa and the Sima de los Huesos site. The Rampa is a $9 \mathrm{~m}$ long ramp. At the end of the Rampa, the Sima de los Huesos deposit opens as a smoothly rectangular $8 \mathrm{~m}$ by $4 \mathrm{~m}$ chamber (Arsuaga et al., 1997). These areas contain twelve distinct lithostratigraphic units that can be grouped into five allostratigraphic members, each delimited by erosive contacts (Fig 2.) (Arnold et al., 2014). This sedimentary sequence from bottom to top consists of re-deposited basal Miocene marls and wellsorted fluvial sands and silts, overlain unconformably by sterile red clays (lower red clays), red clay-silts containing hominin and carnivore bones (upper red clays) and claysilt breccias dominated by bear bones and lithic clasts (café con leche unit). Continuous speleothems and broken isolated fragments of flowstones are found above the basal marls and fluvial sands and silts (LU-2, LU-4), within the upper red clays (LU-2, LU-4) and intercalated with the clay-silt breccia horizons (LU-8). The whole sequence is sealed by an expansive flowstone (Colada, LU-10) and capped by a clay breccia unit containing distinct bat guano horizons.

The SH human fossil association is in unit LU-6 (upper red clays) without relation between river deposits in the plains with karst sedimentation because alluvial terraces at that time, T7 and T8, were lower than levels of speleothems inside LU-6 (Bischoff et al., 2003; Benito, 2004; Ortega et al., 2013). These human remains are mixed with other mammals' bones and are without anatomical connections (Arsuaga et al., 1993). About thirty human individuals were computed from tooth, jaws and limbs in this unit (Arsuaga et al., 1997; Bermúdez de Castro et al., 2004) with predominance of middle age and scarcity of infants and old individuals (Bermúdez de Castro \& Nicolas, 1997; Arsuaga, 1999; Bermúdez de Castro et al., 2004). This human remains concentration is the highest concentration of Homo heidelbergensis in the world and also the most complete collection of Middle Pleistocene Homo. The Sima de los Huesos site contains a large variety of carnivores such as foxes, large felines, wolves, mustelids, and bears, but no herbivores. On the other hand there are no traces of habitation in the $\mathrm{SH}$ site although a single hand axe is associated with this human fossil assemblage (Carbonell \& Mosquera, 2006).

\subsection{Current interpretation}

Various articles propose that there were ritual burials in the Sima de los Huesos site. In summary, there are four aspects which lead to this interpretation. The first is the absence of herbivores in this outcrop, the second the highest concentration of Homo heidelbergensis around the world, the third an Acheulian hand axe and the fourth the human mortality distribution.

The absence of herbivores would mean that carnivores did not use the site as a den and therefore that they did not introduce the human remains into the cave for eating because not a single herbivore was ever carried in (Arsuaga et al., 1997). It is more likely that human and bear bodies were already there and that carnivores came into the cave to eat the carrion. However, the large number of foxes, and the presence of other carnivores, does not support the hypothesis that carnivores visited the site only to scavenge and eventually died there by natural causes, and would support the natural trap hypothesis to explain the carnivore accumulation. Moreover, the age-at-death profile of the bear sample in Sima de los Huesos fits better with a catastrophic profile than with an attritional pattern (García \& Arsuaga, 1997) although, and according to Arsuaga et al. (1997), if human bodies were not introduced by large predators, this would imply that they were carried by human as the null hypothesis (Arsuaga et al., 1997).

The second aspect regarding human burial hypothesis at the Sima de los Huesos site is the bone remains concentration. These fossil remains are mostly concentrated inside a quite discrete sedimentary level, which cannot be explained by any kind of catastrophic event (Carbonell \& Mosquera, 2006; Sala et al., 2014). In the Sima de los Huesos site over twenty-eight Homo heidelbergensis remains were found in only four cubic metres of sediments. This concentration of human fossils indicates ritual burials by this primitive Homo who threw their dead relatives to the cave site as a symbolic act (Arsuaga, 1999; Arsuaga \& Martínez, 1999; Carbonell et al., 2003; Carbonell \& Mosquera, 2006).

The third aspect regarding ritual burials at the Sima de los Huesos site is an Acheulian hand axe. Carbonell claims that Sima de los Huesos was never a hominid occupation site, since no trace of habitation has been discovered and there are no herbivore remains (Carbonell \& Mosquera, 2006). In fact, Sima de los Huesos contains a large variety of carnivores, such as foxes, large felines, wolves, mustelids, and bears. The presence of these specimens may be explained as several events of natural falling, hibernation and catastrophic death, particularly clear in the bears' case. This may be supported by the fact that all these specimens are present along the whole sedimentary sequence. On the contrary, human remains are mostly concentrated inside a quite discrete sedimentary level (Unit LU-6, upper red clay) (Arnold et al., 2014). The finding of an Acheulian hand axe at the Sima de los Huesos site casts light on the evolution of human behaviour during the Middle Pleistocene. It is a finely flaked quartzite hand axe, which is associated with the hominid assemblage. The particular nature of 
(a)
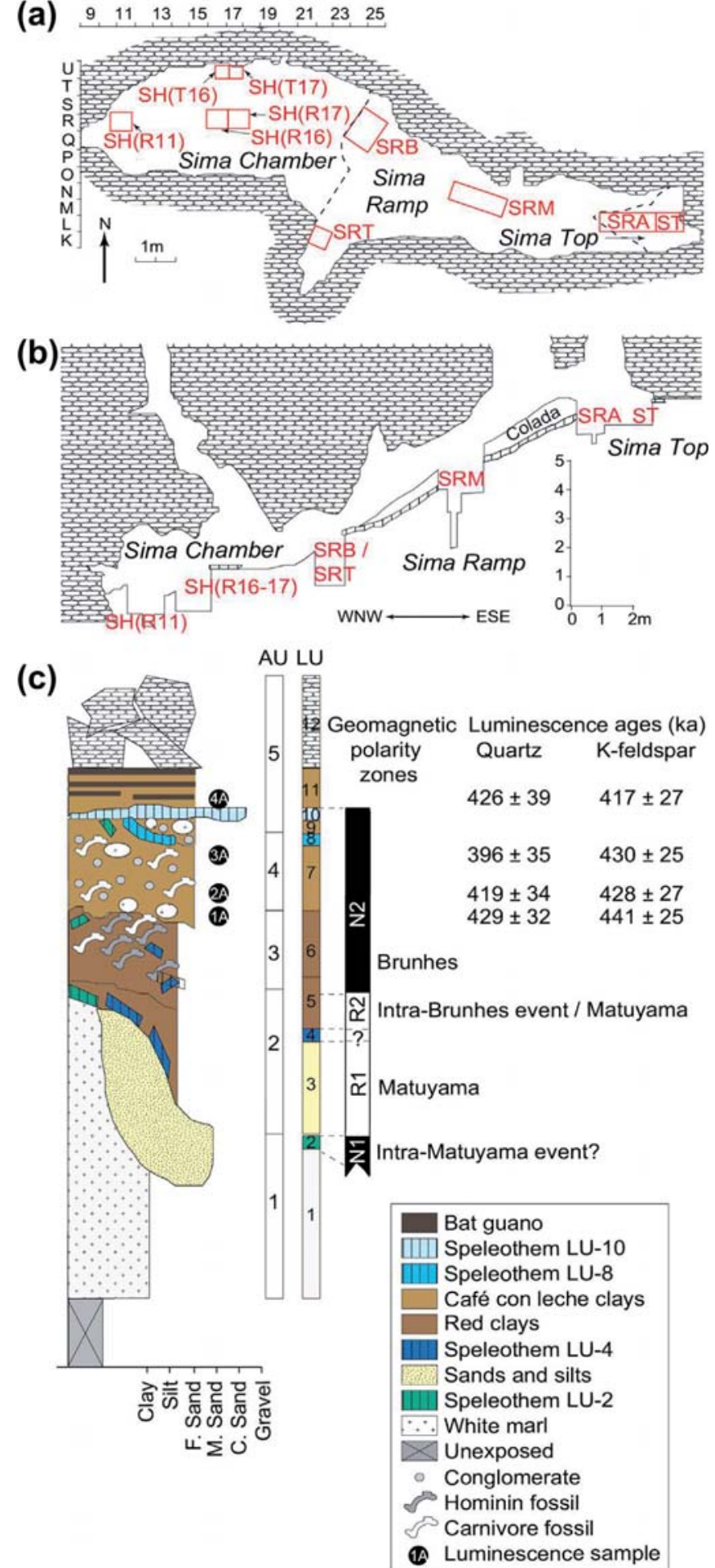

Figure 2. Composite stratigraphic section of Sima de los Huesos site. a) Luminescence dating and palaeomagnetic sampling localities. b) West north-west to east southeast longitudinal transect across the Sima chamber. c) Stratigraphic sequence (Arnold et al., 2014, modified).

the deposit involving its taphonomy, palaeontology, and technology points to a symbolic meaning both of the tool and the human accumulation. This would support the hypothesis of human mortuary practices at the Sima around $400 \mathrm{kyr}$ ago. This discovery allows us to extend human complex behaviour and symbolism of mortuary rituals $300 \mathrm{kyr}$ earlier than broadly heretofore accepted (Carbonell \& Mosquera, 2006). A use-wear analysis could not demonstrate conclusively as to whether this object was actually used, due to erosion of the tool's edges; however, it would seem quite clear that it was not made to be used in the Sima, since the latter was clearly not employed as an occupation site and it was thrown through the shaft as a symbolic act during a ritual burial (Carbonell \& Mosquera, 2006).

The last aspect regarding an anthropic origin for the accumulations at the Sima, and according to the tooth studies, is the lack of infants and children with an abnormally high percentage of adolescents and primeage adults. Also, the number of adults over the age of 20 is lower than expected in normal models (Bermúdez de Castro \& Nicolas, 1997; Arsuaga, 1999). This mortality distribution could be the result of a catastrophe as a sudden death for all Sima de los Huesos human individuals before the ritual burial (Arsuaga, 1999). Later Bocquet-Appel and Arsuaga discarded the hypothesis that the site was a primitive cemetery, suggesting instead that the mortality distribution could be the result of a catastrophe, although they did not specify the origin of the accumulation (Bocquet-Appel \& Arsuaga, 1999).

Considering the biases of the human bone collection - the presence of one hand axe, the human remains concentration and the absence of herbivores - the recognized interpretation is that in Sima de los Huesos there was an accumulation of human bodies for which carnivores were not responsible. On the contrary, the accumulation of human remains could be either catastrophic or the result of a mortuary practice. This explanation should be considered the null hypothesis for future tests (Arsuaga et al., 1993).

In summary, how the human bodies arrived in this small chamber has been one of the most debated issues related to the formation of this site, and different hypotheses have been proposed as the intentional accumulation of corpses inside the chamber (Arsuaga, 1999; Arsuaga \& Martínez, 1999; Carbonell et al., 2003; Carbonell \& Mosquera, 2006; Sala et al., 2014) or a catastrophic event (Díez, 1990; Bocquet-Appel \& Arsuaga, 1999; Aguirre, 2000a, b).

\section{MATERIALS AND METHODS}

In the present work we use data from different authors in order to analyse the SH human fossil association. These papers were obtained by searching in the main palaeontological and palaeoanthropological magazines from USA and Europe using the following keywords: 
Sima de los Huesos human fossil association, Sima de los Huesos taphonomy, Sima de los Huesos human burials, Sima de los Huesos Homo heidelbergensis, and Sima de los Huesos Homo neanderthalensis. This selection includes papers published from 1997 until 2013 and with the abstract in these magazines. These publications were: Journal of Human Evolution, Science, Journal of Archaeological Science, Evolutionary Anthropology, Human Palaeontology and Prehistor, Comptes Rendus Palevol, L'Anthropologie, and American Journal of Physical Anthropology.

\section{TAPHONOMICAL REVIEW}

The Sima de los Huesos human fossil association shows a singular fact which can be analysed with a new perspective. The biases of the human bone collection, the presence of one hand axe, the human remains concentration and the absence of herbivores are not indicative only of a human burial in the SH site. This fact and others will be described in this paper.

\subsection{Vertebrate skeleton proportions at $\mathrm{SH}$}

The Sima de los Huesos site contains mainly a bonebearing breccia with clayish matrix (LU-7). Human remains were discovered in a lower level (LU-6). Therefore human bones are present only in the red clay level (LU-6) in $\mathrm{SH}$, but carnivores (especially bears) are present in both stratigraphic levels (LU-6 and LU-7) (Arsuaga et al., 1997; Bischoff et al., 2007; Arnold et al., 2014). Together with the SH human bones, more than 176 individuals of Ursus deningeri (García \& Arsuaga, 2011) and other carnivores have been recovered, including: Vulpes vulpes (MNI: 21), Canis sp. (MNI: 1), Panthera leo cf. fossilis (MNI: 3), Panthera sp. (jaguar-size; MNI: 1), Felis silvestris (MNI: 1), Lynx pardinus spelaeus (MNI: 2) Martes sp. (MNI: 1), Mustela nivalis (MNI: 2), Mustela putorius (MNI: 3) and Meles meles (MNI: 1) (García \& Arsuaga, 1997, 2011; García, 2003; García \& Arsuaga, 2011). As yet, no ungulate remains have been found at the site.

Human bones are present only in the red clay level (LU-6) in SH, but associated with bone remains of other carnivores, especially bears and canids where the main predators with 50 percent of individuals estimated were bears, followed by humans with 11 percent and foxes with 8 percent. The rest - felids, wolves and weasels - are a minority (García \& Arsuaga, 1997). Therefore, the Sima de los Huesos fossil association has a general absence of herbivores and a clear predominance of bears, hominins and foxes. Human remains are concentrated in the upper red clay of unit LU-6. This red clay is pure, devoid of extraclasts, while the rest of carnivores, bears included, are more frequent in the upper conglomeratic level LU-7 (Arnold et al., 2014).

\subsection{Bone proportions among the human sample}

Initially, in the Sima de los Huesos site thirty-two individuals were computed from 1,300 human remains (Arsuaga et al., 1997) and later, with more than 6,500 remains the minimum number of individuals was twentyeight (Bermúdez de Castro et al., 2004). These human remains, but never entire bodies, have allowed the inference of 27 complete long bones and to estimate for each bone an average body stature of about $163.6 \mathrm{~cm}$ for humans from Sima de los Huesos (Carretero et al., 2012). Therefore there are to date no complete human skeletons with anatomical connections in the Sima de los Huesos site. On the other hand, and if we compare the minimum numbers of skeletal elements for SH human assemblage with the relative abundance of skeletal elements that should correspond to these individuals computed at Sima de los Huesos, we will notice that there is a reduced relative abundance of metacarpal, metatarsal, tarsal, carpals, phalanges, vertebrae and ribs while femora, humeri, mandibles and teeth are the most represented (Andrews \& Fernández-Jalvo, 1997; Fernández-Jalvo \& Andrews, 2001; Sala et al., 2014). Therefore human arms and legs remains are more represented than other parts in Sima de los Huesos human fossil association. Moreover the total number of skeletal parts of these 28 Homo heidelbergensis is not complete which indicates a missing large amount of the original remains, especially phalanges ribs, and vertebrae.

\subsection{Human age distribution}

According to tooth studies, $52 \%$ of these human remains were adolescents and young adults. In fact, $60 \%$ of them were less than 19 years old and $90 \%$ less than 27 (Bermúdez de Castro \& Nicolas, 1997; Arsuaga, 1999). There is only the testimonial presence of one individual under the age of 10 years in the Sima de los Huesos site (Bermúdez de Castro et al., 2004). Therefore there is a clear predominance of middle age human remains and a scarcity of infants and elderly individuals.

\subsection{Human fossil association age}

The Sima de los Huesos human fossil association originated between 205,000 and 325,000 years ago (Parés et al., 2000) but other investigations propose 400,000 and 500,000 years ago (Bermúdez de Castro et al., 2003; 
Bischoff et al., 2003) or more than 427,000 (Arnold et al., 2014). This data dispersion is not a problem of precision in the Sima de los Huesos pit. Given the actual time scale by palaeomagnetism and uranium thorium, much of this fossil human accumulation covered a substantial time span in excess of 100,000 years (Arnold et al., 2014). Therefore the SH fossil association was produced between 205,000 and 500,000 years ago.

\subsection{Hand axe surface}

When Homo stayed in cavities, they carried prey inside for consumption, producing many cut marks on the bones and collections of stone tools as at Cueva del Angel (Barroso et al., 2011). This fact does not apply to in the Sima de los Huesos site although one hand axe was found there (Carbonell et al., 2003; Carbonell \& Mosquera, 2006). This single hand axe was considered as a symbolic object during a ritual burial when Homo heidelbergensis threw this tool into the pit (Carbonell \& Mosquera, 2006). Tracing studies reveal that the hand axe does not exhibit use-wear traces because there is microscopic erosion on the edges of the hand axe. According to experimental data, this abrasion was produced by sandy sediments (Carbonell \& Mosquera, 2006).

\subsection{Abrasions on human bones}

There are no many human cranial remains with abrasions and fractures caused by impacts to these bones (Andrews \& Fernández-Jalvo, 1997; Fernández-Jalvo \& Andrews, 2001). Altogether the proportion of complete bones was 3 $\%$ in the human fossil assemblage of the Sima (Andrews \& Fernández-Jalvo, 1997). In addition, human fossils from the undisturbed deposits had $24 \%$ of transverse breaks rounded and $20 \%$ of spiral breaks eroded showing abrasions over surfaces of fractures (Andrews \& Fernández-Jalvo, 1997).

\subsection{Bite marks on human bones}

Sima de los Huesos human remains show many bite marks on the majority of bones. In fact, fifty percent of the human remains at Sima de los Huesos are affected by bite marks, especially femora at $96 \%$ and, in general, on pelvis and limb bones (Andrews \& Fernández-Jalvo, 1997; Fernández-Jalvo \& Andrews, 2001). According to a recent study (Sala et al., 2014) the femur is the anatomical region that shows the highest incidence of tooth marks, although the marks frequency is less than $20 \%$. After the femur, the humerus is the second most affected anatomical element, and tooth marks are most common on the proximal epiphysis. Three percent of the tibiae also show tooth marks that are concentrated on the distal epiphysis. Radii and ulnae show tooth mark frequencies of 1.59 and 1.69 $\%$, respectively, predominately furrowing and scores. The percentage of carnivore-modified metacarpals is very low, and modification of metatarsals is absent. Both the hand and foot bones (excluding metatarsals and metacarpals, which were included with long bones) show low frequencies of tooth marks, or none at all in some cases. None of the clavicles studied show evidence of modification by carnivores (Sala et al., 2014). All these percentages are consistent with first studies (Andrews \& Fernández-Jalvo, 1997; Fernández-Jalvo \& Andrews, 2001). Therefore these data show that evidence for carnivore activity in the human sample from $\mathrm{SH}$ is concentrated mostly on the epiphyses of long bones and limbs (femora, tibiae and humeri).

The characteristic pattern of rounded epiphyses inflicted by bears (Weigelt, 1989; Domínguez-Rodrigo, 1994) is not found on the human association in Sima de los Huesos. On the other hand, bears predominate in the upper levels of SH outcrop (Unit LU-7) while human remains in the lower levels (Unit LU-6) (Arnold et al., 2014). Namely, there are bite marks from bears on bear bones but not on human bones. On the contrary, there are bite marks from felids or canids on human remains but not on bear bones, although some authors think the opposite (Sala et al., 2014).

\subsection{Alternative old paths to SH}

At the bottom of the vertical shaft which gives access to the Sima at present, there is an opening at the end of the site furthest from the Sima de los Huesos and topographically one or two metres above it. This passage is completely blocked by large boulders at present, but clearly at some time in the past it was not blocked (Ortega et al., 2013). Another is a vertical shaft in the ceiling at the middle of the eastern half of the Sima. Smooth, essentially linear, and about $1 \mathrm{~m}$ in diameter, it extends upward some $5 \mathrm{~m}$ to where it is choked by a collapse breakdown (Arsuaga et al., 1997). Nevertheless some fallen rocks are around the Sima area which implies an old upper entrance during the Middle Pleistocene (Carbonell \& Mosquera, 2006). These and other accesses were described in the Sima de los Huesos site (Ortega et al., 2013) but they were discarded as old passages and were considered sealed 400,000 years ago (Arsuaga et al., 1997). Nowadays there is no age data on any of these slumps.

\section{DISCUSSION}

The problem of the Sima de los Huesos site is the absence of similar outcrops with equivalent geology and fossil assemblage. The main findings about treatment of the 
deaths during the Pleistocene age come from repeated studies of cut marks, scraping marks, bone breakage of human bones regarded as deliberate mortuary practices (Ullrich, 1999) but none of these factors are observed at the Sima de los Huesos site. The occurrence and situation of this outcrop has very few known parallels for the Palaeolithic record. One of them might be the Cueva del Angel, near Córdoba in Andalusia, Spain (Barroso et al., 2011), where a very deep cleft has been identified with animal food refuse, hand axes and human remains inside. At any rate, the Sima de los Huesos site only contains human and carnivore remains while Cueva del Angel represents something very different. The assemblage of large herbivores in the Cueva del Angel corresponds to an accumulation of anthropic origin during a long period from the end of the Middle Pleistocene to the beginning of the Upper Pleistocene where humans brought large quantities of meat into the cave, essentially horses and bovids, in dismembered and cut forms (Barroso et al., 2011). The Cueva del Angel fossil assemblage shows an appreciable number of cut marks and striations ( $9 \%$ of the material) related to defleshing, filleting and disarticulation, and high proportion of burnt elements ( $88 \%$ of the material) while these characteristics do not exit in the Sima de los Huesos fossil assemblage. Therefore this outcrop has no direct taphonomical relation with the Sima de los Huesos outcrop. Cueva del Angel was a site of intense and continuous occupation for butchering and cooking of animal meat resources predated and transported into the cave by humans whereas this is not the case at Sima de los Huesos. Therefore, and for the time being, we have to focus our attention only in taphonomical and geological data of the Sima.

\subsection{Human age distribution}

The Sima de los Huesos human age distribution can reflect the mortality rate of the original population. The infant and old mortality rate is very high in current hunter-gatherers (Howell, 1979; Jones et al., 1992) which also occurred in Neanderthal or Homo heidelbergensis populations (Trinkaus, 1995). On the other hand the fragile and delicate remains of infants and children are more severely affected by the action of biostratinomic and fossildiagenetic agents than bones from adolescents and adults although caves minimise weather action (Hill, 1979; Haynes, 1980). In Sima de los Huesos two hyoid bones and nearly 30 middle ear bones were found (Martínez et al., 2012). Therefore we suppose that the fossil preservation in the Sima de los Huesos site is excellent and the distribution of human ages has to reflect the original corpses number. Accordingly, humans between 0 and 11 years old and over 27 were underrepresented in the Sima de los Huesos site. This predominance of middle age and scarcity of infants and old individuals does not indicate a mortality rate but rather something very different; an accident risk rate (Rabadà, 2001). Teens and young adults tend to be fearless and they leave the household more than infants and older people. This fact implies a higher than expected mortality rate in young humans due to contingencies, such as would be inferred by ritual burial. In fact, some authors have discarded the hypothesis that the site was a primitive cemetery because the mortality distribution was the result of a single catastrophe for all human individuals, although they did not specify the origin of the accumulation and did not explain this human remains concentration (Bocquet-Appel \& Arsuaga, 1999). Even so there are different allochthonous sedimentary horizons overlying the hominin-bearing clay breccia (Arnold et al., 2014). These speleothems indicate different supplies of sediments during the formation of the Sima de los Huesos fossil association which does not support a single catastrophic event as Bocquet-Appel and Arsuaga claimed. In summary, we propose that different accidents or contingencies caused the initial human bones accumulation near the SH pit.

\subsection{Abrasions on human bones}

The scarce human cranial remains with abrasions were interpreted by some authors as impacts from stones when these old humans were fighting or playing with each other (Arsuaga, 1999), but it seems more logical that these scars were produced when water currents moved the human remains in the cave as suggested by Andrews and Fernandez-Jalvo (1997). Weigelt (1989) and White et al. (1984) described bone trauma in fallen animals in potholes as a trap but there is an inconsistency in the case of the Sima. When animals fall into a pit inaccessible to predators they tend to generate fossil associations without bite marks while human remains in the Sima are full of them. On the other hand, and according to the hypothesis that other humans threw dead bodies into the $13 \mathrm{~m}$ shaft, an experiment was performed using human bones to determine the degree of breakage by dropping them from a $13 \mathrm{~m}$ height on to a hard concrete surface (Andrews \& Fernández-Jalvo, 1997). In the event, most of the bones did not break or were damaged in any way. Altogether the proportion of complete bones was $82 \%$, very different from the $3 \%$ in the fossil assemblage of the Sima. This fact does not support the hypothesis that other humans threw dead bodies into the pit (Andrews \& FernándezJalvo, 1997).

There exists another kind of abrasion on human bones; those found on fracture surfaces. It is assumed that transverse breaks occur when bones are partially mineralized, and spiral breaks occur at the time of death or soon thereafter. The greater degree of rounding on the transverse breaks indicates that the process producing the 
rounding must have operated at a time considerably after burial and it suggests reworking as a result of movement of the bones in the sediment. It has been demonstrated that abrasion by silty clay matrix may produce rounding of fossilised bones more rapidly than fresh bone (FernándezJalvo \& Andrews, 2001), which again suggests modification some time after deposition (Andrews \& Fernández-Jalvo, 1997). In summary, the fossil association of the Sima was mixed and eroded by the cave water currents but not thrown into the pit.

\subsection{Percentage of human bones and bite marks}

With respect to carnivore modification in the SH human sample, a first study suggested that carnivores can be excluded as major agents involved in the accumulation of human remains due to the absence of tooth marks (Arsuaga et al., 1990). In a recent study, carnivore modification rates on human bones do not exceed $8 \%$ (Sala et al., 2014). For these authors the low frequency of tooth marked bones alone cannot provide them with sufficiently convincing information about the carnivore responsible for this bone concentration. These authors think that this low percentage rejects any important contribution from predators on $\mathrm{SH}$ human remains. We think the problem with this viewpoint is that there are a lot of current bone samples caused by predators with very low carnivore modification rates (Brain, 1958, 1981) which is consistent with the SH site. Moreover bite marks number depends on the availability of food. Carnivores gnaw less bones when hunting is abundant (Brain, 1958, 1981). We assume that the low rate of bites in $\mathrm{SH}$ implies that the ecosystem in Atapuerca had high biological productivity. In fact, the carnivore taxonomic diversity found in Sima de los Huesos is particularly high corresponding to high ecosystem productivity (García, 2003). This is consistent with the high biodiversity of SH carnivores (García \& Arsuaga, 2011). Therefore, we think that this lower rate of bites does not mean no action carnivore but high productivity of the ecosystem.

Another aspect to consider was the method of Salas et al. (2014). They analysed only 2,401 human remains from 6,500 $\mathrm{SH}$ human bones which could explain the low carnivore modification rates with respect to $50 \%$ in other studies (Fernández-Jalvo \& Andrews, 2001). To date, only two studies in the past two decades have proposed different hypotheses to explain carnivore activity in the SH human sample. The first was between 1997 and 2001 (Andrews \& Fernández-Jalvo, 1997; Fernández-Jalvo \& Andrews, 2001), and the second seventeen years later (Sala et al., 2014). Both studies agree with a predominance of human arm and leg remains in the Sima de los Huesos site. Limb bones such as femurs, humeri and tibiae are more represented than ribs, vertebrae, metacarpal, metatarsal, tarsal, carpals and phalanges according to twenty-eight computed individuals. On the other hand the total number of skeletal parts of these twenty-eight Homo heidelbergensis is not complete, indicating two things. Firstly, a large amount of the original remains is missing, especially phalanges and vertebrae (Andrews \& FernándezJalvo, 1997; Fernández-Jalvo \& Andrews, 2001), and secondly this fossil association is dispersed within the cave. If human remains were carried into a pit as a sepulchral rite we have to suppose that these were whole bodies and not parts of them. Therefore, we should find less dispersion and dismantling. All this involves a partial and selective transport of human bones at the Sima de los Huesos site as Andrews and Fernandez-Jalvo (1997) suggested. In addition, limbs contain a large quantity of meat for feeding while ribs, vertebrae, metacarpal, metatarsal, tarsal, carpals and phalanges do not because they contain relatively little nutritional value (Bailey, 1993). Lions, leopards, hyenas or other animals produced this kind of bone accumulation with predominance of arms and legs with a large quantity of meat. For this reason, carnivores rarely fragment metacarpal, metatarsal, tarsal, carpals and phalanges; a fact which is consistent with the $\mathrm{SH}$ fossil assemblage. For instance, phalanges are nearly absent from many modern hyena dens, and fossil carnivore accumulations often exhibit low numbers of them (Hutson, 2008). Moreover fifty percent of the human remains at Sima de los Huesos are affected by bite marks, especially femora and, in general, on limb bones (Andrews \& Fernández-Jalvo, 1997; Fernández-Jalvo \& Andrews, 2001). The same predominance has been described by Sala et al. (2014) but with a lower percentage of bones affected by bite marks. The presence of bear remains associated with human bones in LU-6 level suggested initially that those predators perpetrated these bite marks (Rabadà, 2001; Sala et al., 2014). The low frequency of tooth-marked bones and the size of these bite marks are compatible, a priori, with bear and feline activity (Sala \& Arsuaga, 2013; Saladié et al., 2013; Sala et al., 2014). In accordance with all of these reasons, the aforementioned authors believe that bears were the carnivores responsible for modifying the hominin bones but that these similar dimensions do not justify the same origin. In fact, the dimensions of tooth marks on the Ursus deningeri fossils from the $\mathrm{SH}$ human assemblage do not differ significantly and this interpretation is not consistent with taphonomical data on fossils of bears. In fact bears chew bones producing a characteristic pattern with rounded epiphyses (Weigelt, 1989; Domínguez-Rodrigo, 1994) which is not found on the human association at Sima de los Huesos. On the other hand, bears predominate in the upper levels of the SH outcrop, unit LU-7, as opposed to human remains in the lower, unit LU-6. Specifically, human remains are concentrated in the upper red clay of unit LU-6 while the rest of carnivores are more frequent in the conglomeratic unit LU-7 (Arnold et al., 2014). 
Moreover there are bite marks from bears on bear bones but not on human bones. On the contrary, there are bite marks from felids or canids on human remains but not on bear bones. All these reasons indicate to these authors that bear and human remains were separated at the start and were mixed later by water currents leading to the observed abrasion on bones (Andrews \& Fernández-Jalvo, 1997; Fernández-Jalvo \& Andrews, 2001; FernándezJalvo, 2003). For instance, occasional excavation of in situ and ex situ deposits near a vertical cave entrance at the formerly mined Plio-Pleistocene Gondolin palaeocave system has yielded large and diverse samples of faunas including isolated hominin and non-hominin remains mixed and eroded by cave water currents (Adams et al., 2007). This study highlights the variation in taphonomic processes that can occur within a single cave system, and the complex pre- and postdepositional geological and hydrological processes which can influence the history of karstic fossil assemblages. To date it has been conclusively demonstrated that the majority of bear remains entered the Sima separately from the human remains. This situation would suggest that definitively bears did not bite and produced the human bone accumulation in the Sima de los Huesos site (Arnold et al., 2014). On the other hand, a very close relative of the extinguished cave bear, the current European bear, eats its prey outside caves without moving it to the cavities. In fact, bears used to hibernate inside caves where they were eaten by their own species producing the rounded epiphyses. This process explains the accumulation of bear bones inside cavities (Haynes, 1983; Weigelt, 1989; Domínguez-Rodrigo, 1994) and the bear fossil association in the Sima where they were eaten by their own species around or inside the pit (García \& Arsuaga, 1997; García, 2003).

Another important aspect concerning bears, Homo and other carnivores is the close relation between these species. Bears, Homo heidelbergensis, lions and hyenas used caves as a temporary shelter for millennia, bears as a hibernation place, lions and hyenas as den and humans as a campsite. In summary, we assume that the common ground between them was their specialised carnivorous strategies as predators, and their competing for similar food resources and caves as a resting place. Therefore the Atapuerca range represented an area of ecological competition between all these predators.

Based on current knowledge it is unclear which carnivores were responsible for bite marks on human remains at the Sima de los Huesos site. The analysis of tooth marks found on human bones shows different patterns between anatomical elements and the size of these bites. These sizes and distribution of carnivore pits indicate two predator groups (Andrews \& FernándezJalvo, 1997; Sala et al., 2014). Femora, tibiae, humeri and radii were chewed more by small scavengers. On the other hand pelvis and lumbar vertebrae were chewed by large predators. In fact chewing-marks by small carnivores are absent on the latter elements. Therefore, these marks follow, from high to low abundance, the consumption sequence for flesh ingestion, with the highest percentage on pelvis and limbs and the lowest on ulna and radius (Blumenschine, 1986). Therefore, a large carnivore is considered to have had priority access to the human bodies at $\mathrm{SH}$, because hindquarters (axial parts) are affected by their teeth in higher proportions than other elements (Andrews \& Fernández-Jalvo, 1997). Small carnivore activity, therefore, is consistent with scavenging rather than predation. All those carnivores produced the first human bone association with a high percentage of limbs. Some authors think that Panthera leo fossilis and Vulpes vulpes were the carnivores which produced the main bite marks (Fernández-Jalvo \& Andrews, 2001) although other authors have proposed that these signs of carnivore activity in the SH sample appear very infrequently; a fact which they interpret as indicating that carnivore activity was very sporadic at this site (Sala, 2012; Sala \& Arsuaga, 2013; Sala et al., 2014). This scenario contrasts significantly with initial studies (Andrews \& Fernández-Jalvo, 1997; Fernández-Jalvo \& Andrews, 2001; Bermúdez et al., 2004). In any case, we think that the original authors cannot deny carnivore activity in the SH sample. In fact these original authors only try to minimise, rather than reject, the carnivore activity on the SH human bones sample seventeen years after the initial studies. Moreover they have investigated only the bones that provide relevant information regarding carnivore modification, e.g., long and flat bones (innominate, cranial, costal and vertebral remains). Sala et al. (2014) analysed only a total of 2,401 human fossils from 6,500 $\mathrm{SH}$ human remains. Dental remains and bone fragments smaller than $1 \mathrm{~cm}$ were excluded although these remains were broken very probably by predators. Perhaps for this reason the analysis of the sample of 2,401 human fossils from $\mathrm{SH}$ shows lower carnivore activity rates with respect to $50 \%$ from first studies. Unfortunately, it is difficult to compare these original works (Andrews \& Fernández-Jalvo, 1997; Fernández-Jalvo \& Andrews, 2001) with the recent study (Sala et al., 2014) because the latter study does not include all fossil specimens and therefore it is impossible to determinate which fossils have discrepancies between the two studies. On the other hand, the method of analyses of bite marks is different between the two papers. The first analyses the number and size of marks on human remains and the second considers that large and small carnivores are best differentiated using the tooth pit mean rather than size ranges (Andrés et al., 2012). They think (Andrés et al., 2012; Sala, 2012; Sala et al., 2012, 2014) that the tooth pit length on shafts is the best indicator of the carnivore taxa responsible for the marks. For this reason, they focused particularly on this feature and created a method which leads to discrepancies between both studies. 
Regardless of the above, cave water currents transported and eroded all these human bones later. Therefore we can say that incisions on human bones were caused by wolves, foxes and some large predator. The latter had access to the remains before canids. In fact, opportunistic predators such as lion or leopard used to concentrate bones. Since Pleistocene hominid hunter-gatherers are regarded as apex carnivores in a competitive carnivore guild (Eaton, 1994). The total of some twenty-eight individuals at the Sima de los Huesos site as prey would not be out of character with a comparatively low rate of predation on ancient humans by medium or large carnivores at the site. Therefore large carnivores hunted human individuals during the Pleistocene and many carnivore species were involved. Spotted hyenas, and their proximal Pleistocene ancestors, Crocuta spelaea, are known to dig up buried humans in Ethiopia, and equivalent examples are to be found in some Late Pleistocene caves with Neanderthal remains in Southwest France, and also in Monte Circeo, Italy, or the Homo erectus accumulation in Locality 1 of Zhoukoudian which has been interpreted as a human assemblage collected by Pachycrocuta brevirostris (Boaz et al., 2004). Nonetheless hyenas use to break bones with high intensity (Palmqvist et al., 2011; Sala et al., 2012). We assume, in accordance with the low fracture level in this fossil association, that hyena was not the main bonecracking perpetrator. Therefore, and very probably, large felids first ate human flesh near the Sima de los Huesos site and later scavengers chewed the rest. We think that this entire predation context is consistent with the human age distribution. The mortality distribution with a predominance of middle age and scarcity of infants and old individuals implies accidents of some kind, such as depredation.

\subsection{Absence of ungulate remains}

The absence of ungulate remains in the Sima site is not strange. Some caves are known in a great variety of circumstances where carnivores are the only fossil animals. For instance, the reconstructed taphonomic and palaeoenvironmental contexts of a 4 million-year-old partial hominid skeleton (Stw 573) from Sterkfontein Member 2 shows a mammalian faunal assemblage associated stratigraphically with the hominid dominated by cercopithecoids (Parapapio and Papio) and felids (Panthera pardus, Panthera leo, Felis caracal, and Felidae indet.) but not herbivores. In addition, the assemblage is characterised by a number of partial skeletons of bones across all taxonomic groups. In fact there is scant indication of carnivore chewing in the assemblage (Rayne et al., 2004) as occurred at Sima. Another example is the late Pleistocene asphalt seeps of Rancho La Brea where an assemblage of carnivores with a large number of dire wolf and sabertooth cat specimens is more frequent than herbivores remains. The hypothesis that predators engaged in intense competition for trapped prey explains their predominance and the mechanism of this predator trap (McHorse et al., 2012). Therefore the predominance of carnivore specimens in the Rancho La Brea deposits has long been explained by a scenario in which a prey animal was trapped and attracted large numbers of carnivores who became trapped in turn (Spencer et al., 2003). However, patterns of skeletal part representation for the seven most common species demonstrate that complete skeletons are not present. Water transport, as at the Sima de los Huesos site, has been ruled out as the primary process responsible for removing skeletal elements based on abrasion data. Instead, the feeding activity of carnivores and the ecological context appear to have been an important factor in the formation of the assemblage (Spencer et al., 2003). In summary, we asume that very different landscapes and contexts explain the predominance or absence of herbivores in cave deposits as the Sima de los Huesos site. Therefore, the scene context is very important for knowing bone association factors.

The Sima de los Huesos site was located in a small range far away from the plains (Benito, 2004) where large felids hunted herbivores and ate them in this meseta around the current Atapuerca range (Rabadà, 2007). We asume that herbivores do not stay for long periods in mountains and forests because they prefer open fields to avoid predators and in caves there is no grass for them. In addition, large predators such as lions and leopards move corpses only a hundred metres (Schaller, 1972; Kitchner, 1991; Bailey, 1993) but the Sima de los Huesos site was a long way from the plains (Benito, 2004). On the other hand, the carnivore taxonomic diversity found in Sima de los Huesos is particularly high corresponding to high ecosystem productivity (García, 2003). We think this implies two things: there were many herbivores living in those plains and the Atapuerca range represented an area of ecological competition between all their carnivores, Homo included, who suffered a high risk of contingencies such as predation by large carnivores.

\subsection{In and out}

The next problem to solve is how large felids came into and out of the pit if they really ate human flesh at the bottom of the Sima. We asume that they ate young and inexpert humans while canines came later for scavenging. Nowadays the Sima de los Huesos site is located at the bottom of a shaft 13 metres deep but caves change a lot during geological processes. In fact, water does not dilute limestone in a karst system entering and exiting through the same place. The cavities formation produced accesses higher than others. Water flows in via upper entrances and 
escapes by lower. Collapse and debris flows happen during this process burying old entrances and exits. Therefore, we suppose that there were more accesses in the Sima de los Huesos site. In fact, there are various blocked passages in the Sima as we have described in chapter 3.8. (Ortega et al., 2013). In any case, all those cavities, or at least one of them, were the access at that time and would explain the entrances and exits of carnivores around the pit as a feeding place. We propose that they produced the primary accumulation of human remains which was then transported and reworked by water currents later on. When the cave was subsequently sealed by slumps, the only entrance was the current pit where accidental falling introduced the majority of bears remains during hibernation. For this reason human remains were concentrated first in the lower unit LU-6 while bears were more frequent later in the upper conglomeratic unit LU-7.

\subsection{Human bone remains concentration}

The Sima de los Huesos site shows a high concentration of human bone remains with excellent fossil preservation. The discussion on this site should be focused on the mechanisms resulting in bone concentration.

There are many causes which accumulate skeletal remains in caves and caverns (Brain, 1958, 1981; Behrensmeyer, 1978; Weigelt, 1989; Andrews, 1990; Domínguez-Rodrigo, 1994). The presence of vertebrate fossils in caves can be caused by rodents or predators carrying the bones, hibernation, reproduction, natural traps, mud and debris flows, sudden death by karst collapse, flooding inside cavity or illness affecting a group of organisms. All these mechanisms have explained the presence of skeletal remains inside caves, but not necessarily their concentration. There are three contexts which can produce bone concentration. The first context is a supply of corpses for a short time period (Andrews, 1990), the second one is gradual supplies over a long period (Andrews, 1990) and the third one a low sedimentation rate (Rabadà, 1990). Combinations of these three contexts accumulate and concentrate bones inside caves.

The first possibility, i.e., a continuous supply of dead bodies is common in colonial animals. An example of these are bats (Andrews, 1990) although the hunter-gatherers current population density is very low (Howell, 1979; Jones et al., 1992) as well as social predators such as wolves and felines (Vicente et al., 1999). Predators need large areas for survival implying a very low population density. Moreover we think that the absence of cut marks in Sima de los Huesos bones indicates that there was not a substantial hominid colony inside or near the pit. On the other hand, there are different allochthonous sedimentary horizons overlying the hominin-bearing clay breccia (Arnold et al., 2014). We asume that these speleothems indicate different supplies of sediments during the formation of this fossil association. Therefore, predators do not give rise to a continuous supply of dead bodies inside $\mathrm{SH}$ and the concentration of corpses in the Sima was caused by other processes.

The second reason for the concentration of bones, i.e., a gradual contribution of remains over long periods, has many examples including feeding regurgitation by owls and eagles (Andrews, 1990), feeding troughs (Brain, 1958), falls into trap chambers (Morris, 1974; White et al., 1984; Andrews, 1990), troughs (Vrba, 1980) and hibernating places (Kurtén, 1958, 1976). Feeding troughs near the Sima site were an easy interpretation for human remains in the Sima de los Huesos outcrop (Rabadà, 2007). We asume that this situation leads to a gradual supply of corpses producing the bone concentration.

The third context, i.e., low sedimentation rates, also led to the observed concentration of bones. Cave clays belong to the insoluble limestone fraction. Cavities are due to calcium carbonate dissolution. A high percentage of limestone is soluble in water, but some clays are not. Therefore, clay generation during cave formation is scarce and karst cavities are not usually associated with rapid burial mechanisms (Smith, 1975; Atkinson \& Smith, 1976; Sorriaux, 1982). The red clay of level LU-6 is pure, devoid of extraclasts, and indicates low energy accumulation which is compelling evidence that the fossils were subjected to shortdistance transport (Aranburu et al., submitted) from a den near the pit. We asume that this context is associated with the observed low sedimentation rate in Sima de los Huesos and the observed bones concentration in the red clay unit LU-6 (Rabadà, 2007). The idea is simple; many bones in a low clay percentage produce a level of bone condensation. We think that this new explanation is consistent with three aspects from the SH site. Firstly, the low sedimentation production allowed a high bone transport rate in karst, which led to the observed bone fragmentation and abrasion by reworking. More than $24 \%$ of the bones are eroded by water currents which transported this first fossil assemblage. Secondly, mixed fauna such as the Sima de los Huesos fossil association happens very often in fossil concentration levels. Thirdly, the different sedimentation ages found in the outcrop are consistent with a fossil concentration level. According to a first sample this age was between 325,000 and 205,000 years old (Parés et al., 2000), but another calculation proposed an age of between 400,000 and 500,000 years (Bermúdez de Castro et al., 2003; Bischoff et al., 2003) or more than 427,000 years (Arnold et al., 2014). Condensation levels mix fossils from different ages as happened in Sima de los Huesos. This data dispersion was due to a low sedimentation rate in the Sima de los Huesos pit. From a derivation of the actual time scale by palaeomagnetism and uranium thorium, much of this fossil human accumulation covered a substantial time 
span in excess of 100,000 years. For instance, the Rancho La Brea tar pits reveal a complex history of accumulation, concentration and diagenesis for specimens found there. Radiometric dating of 46 bones from Pit 91 documents at least two episodes of deposition, one from 45,000 to $35,000 \mathrm{yr}$ and another, shorter interval from 26,500 to 23,000 yr. (Friscia et al., 2008). In summary, we propose that gradual supplies of corpses over a long time period and a low sedimentation rate might produce the observed fossil concentration at the Sima de los Huesos site.

\subsection{One hand axe}

The only one hand axe found in Sima de los Huesos site was considered as a symbolic object during a ritual burial when Homo heidelbergensis threw this tool into the pit (Carbonell \& Mosquera, 2006). Tracing studies reveal that the hand axe does not show use-wear marks because there is microscopic erosion on the edges of the hand axe. According to experimental data, this abrasion was produced by sandy sediments (Carbonell \& Mosquera, 2006). Therefore, we assume that this hand axe was a reworked element as occurred in the rest of the human remains.

\section{CONCLUSIONS}

Only one interpretation does not explain natural processes because these are consequences of a network of causes. The Sima de los Huesos fossil association was considered only as a human burial site by other authors, but according to this bibliographic data review the Sima de los Huesos site may be proposed as originated by several mechanisms. Competition between Homo and other predators for the cavity involved that Homo was a victim of large predators that carried the corpses around the pit in a feeding trough for predators while the cave had other entrances blocked nowadays. In fact the human mortality distribution with a predominance of middle age and scarcity of infants and old individuals implies accidents of some kind, such as depredation. Canines and other scavengers came later for feeding as other authors have proposed. In addition the low rate of bites in SH implies that the ecosystem in Atapuerca had high biological productivity. In fact, the carnivore taxonomic diversity found in Sima de los Huesos is particularly high corresponding to high ecosystem productivity. This context implies that there were many herbivores living in those plains and the Atapuerca range represented an area of ecological competition between all their carnivores, Homo included, who suffered a high risk of contingencies such as predation by large carnivores. Finally water flows in the karst during heavy rainfalls transported, produced dispersion, mixing and abrasion in the human remains. During all these processes a low sedimentation rate and gradual supplies of corpses over a long period of time produced the observed fossil concentration in unit LU-6. In fact speleothems levels indicate different supplies of sediments during the formation of this fossil association. All these human bones concentration is consistent with three aspects from the $\mathrm{SH}$ site. Firstly, the low sedimentation production allowed a high bone transport rate in karst, which led to the observed bone fragmentation and abrasion by reworking. Secondly, mixed fauna happens very often in fossil concentration levels. Thirdly, the different sedimentation ages found in the outcrop are consistent with a fossil concentration level. Later, when the cave was closed by slumps and the main entrance was the current pit, bears fell by accident or died while hibernating there during the sedimentation of the unit LU-7. All these aspects explain the Sima de los Huesos fossil association.

\section{ACKNOWLEDGEMENTS}

The author would like to thank the following organizations and universities: Museu de Geologia del Seminari de Barcelona, CSIC Institut Jaume Almera of Barcelona, UB Facultat de Geologia, Fòrum de Debats de Vic, Centre d'Estudis del Gaià, EJIP, Col·legi de Doctors i Llicenciats de Catalunya, Departament d'Ensenyament and Universitat de València. We are grateful to the following professors, scientists and professionals for sharing their considerable knowledge about taphonomy and cave geology: Carles Ferrández, Francisco Poyato, Antonio López Valverde, Francesc Ribot, Francesc Burjachs, Jordi Maria de Gibert, Peter Andrews, Yolanda Fernández-Jalvo, Jordi Martinell, Rosa Doménech, Miquel de Renzi, Joan Madurell, Lluis Gibert, Julio Aguirre, Sebastián Calzada, Xavier Martínez Delclós, Josep Maria Mata, Chris Stringer, Enrique Gil Bazán, Tatiana Gaona, Paul Talbott, Ivette Grima, Núria Gutiérrez and two anonymous reviewers.

\section{REFERENCES}

Adams, J., Herries, A., Kuykendall, K. \& Conroy, G. 2007. Taphonomy of a South African cave: geological and hydrological influences on the GD 1 fossil assemblage at Gondolin, a Plio-Pleistocene palaeocave system in the Northwest Province, South Africa. Quaternary Science Reviews, 26, 2526-2543.

Aguirre, E. 2000a. Modelo de la Evolución Humana. Registro de Atapuerca. In: Horizontes culturales. Las fronteras de la Ciencia. Real Academia de Ciencias. Espasa, España, 131-162. 
Aguirre, E. 2000b. Sima de los Huesos. Escenarios de la formación del yacimiento, crítica y sesgo demográfico. In: Tendencias Actuales de Investigación en la Antropología Física Española (eds. Dobón, L.C., Otero, H.R., Compadre, B.S., Martínez, B.L. \& Blanco, M.J.). Universidad de Léon, León, 31-42.

Andrés, M., Gidna, A. O., Yravedra, J. \& DomínguezRodrigo, M. 2012. A study of dimensional differences of tooth marks (pits and scores) on bones modified by small and large carnivores. Archaeological Anthropology Science, 4, 209-219.

Andrews, P. 1990. Owls, Caves and Fossils: predation and accumulation of small mammals bones in caves with analyses of the Pleistocene cave faunas from Westburysub-Mendip, Somerset, UK. British Museum of Natural History, London.

Andrews, P. \& Fernández-Jalvo, Y. 1997. Surface modifications of the Sima de los Huesos fossil humans. Journal of Human Evolution, 33, 191-217.

Aranburu, A., Arsuaga, J.L. \& Sala, N. The geology of the Sima de los Huesos (Atapuerca, Spain) and implications for the origin of the fossil hominin accumulation. Journal of Human Evolution (submitted for publication).

Arnold, L., Demuro, M., Parés, J.M., Arsuaga, J.L., Aranburu, A., Bermúdez de Castro, J.M. \& Carbonell, E. 2014. Luminescence dating and palaeomagnetic age constraint on hominins from Sima de los Huesos, Atapuerca, Spain. Journal of Human Evolution, 67, 85-107.

Arsuaga, J.L. 1999. El Collar del Neandertal. Tanto por saber. Ediciones Temas de Hoy, Madrid.

Arsuaga, J.L. \& Martínez, I. 1999. La Especie Elegida. Tanto por saber. Ediciones Temas de Hoy, Madrid.

Arsuaga, J.L., Carretero, J.M., Gracia, A. \& Martínez, I. 1990. Taphonomical analysis of the human sample from the Sima de los Huesos Middle Pleistocene site (Atapuerca/ Ibeas, Spain). Journal of Human Evolution, 5, 505-513.

Arsuaga, J.L., Martínez, I., Gracia, A., Carretero, J.M. \& Carbonell, E. 1993. Three new humans skulls from the Sima de los Huesos Middle Pleistocene site in Sierra de Atapuerca, Spain. Nature, 362, 534-537.

Arsuaga, J.L., Martínez, I., Gracia, A., Carretero, J.M., Lorenzo, C., García, N. \& Ortega, A.I. 1997. Sima de los Huesos (Sierra de Atapuerca, Spain) the site. Journal of Human Evolution, 33, 109-127.

Arsuaga, J.L., Martínez, I., Arnold, L.J., Aranburu, A., Gracia-Téllez, A., Sharp, W.D., Quam, R.M., Falguères, C., Pantoja-Pérez, A., Bischoff, J., Poza-Rey, E., Parés, J.M., Carretero, J.M., Demuro, M., Lorenzo, C., Sala, N., Martinón-Torres, M., García, N., Alcázar de Velasco, A., Cuenca-Bescós, G., Gómez-Olivencia, A., Moreno, D., Pablos, A., Shen, C.C., Rodríguez, L., Ortega, A.I., García, R., Bonmatí, A., Bermúdez de Castro, J.M. \& Carbonell, E. 2014. Neandertal roots: Cranial and chronological evidence from Sima de los Huesos. Science, 344, 13581362.

Atkinson, T.C. \& Smith, D.I. 1976. The erosion of limestones. In: The Science of Speleology, (eds. Ford, T.W. \& Cullingford, C.H.). Academic Press, London, 151-177.
Bailey, T. 1993. The African Leopard. Columbia University Press, New York.

Barroso, C., Botella, D., Caparrós, M., Moigne, A.M., Celiberti, V., Testu, A., Barsky, D., Notter, O., Riquelme, J.M., Pozo, M., Carretero, M.I., Monge, G., Khatib, S., Saos, T., Gregoire, S., Bailón, S., García, J.A., Cabral, A.L., Djerrab, A., George, I., Abdessadok, S., Batalla, G., Astier, N., Bertin, L., Boulbes, N., Cauche, D., Filoux, A., Hanquet, C., Milizia, C., Moutoussamy, J., Rossoni, E., Verdú, L. \& Lumley, H. 2011. The Cueva del Angel (Lucena, Spain): An Acheulean hunters habitat in the South of the Iberian Peninsula. Quaternary International, 243, 105-126.

Behrensmeyer, A. K. 1978. Taphonomy and ecology information from bone wethering. Paleobiology, 4, 150-162.

Benito, A. 2004. Análisis geomorfológico y reconstrucción de los paleopaisajes neógenos y cuaternarios en la Sierra de Atapuerca y el valle medio del río Arlazón. $\mathrm{PhD}$ Thesis, Universidad Complutense de Madrid (unplublished).

Bermúdez de Castro, J.M. \& Nicolás, E. 1997. Paleodemography of the Atapuerca-SH Middle Pleistocene hominid sample. Journal of Human Evolution, 33, 333-335.

Bermúdez de Castro, J.M., Arsuaga, J.L., Carbonell, E., Rosas, A., Martínez, I. \& Mosquera, M. 1997. A hominid from Pleistocene of Atapuerca, Spain: possible ancestor to neandertals and modern humans. Science, 276, 1392-1395.

Bermúdez de Castro, J.M., Martinón-Torres, M., Sarmiento, S. \& Lozano, M. 2003. Gran Dolina TD-6 versus Sima de los Huesos dental samples from Atapuerca: evidence of discontinuity in the European Pleistocene population? Journal of Archaeological Science, 30, 1421-1428.

Bermúdez de Castro, J.M., Martinón-Torres, M., Carbonell, E., Sarmiento, S., Rosas, A., Van der made, J. \& Lozano, M. 2004. The Atapuerca sites and their contribution to the knowledge of human evolution in Europe. Evolutionary Anthropology, 13, 25-41.

Bischoff, J. L., Shamp, D.D., Aranburu, A., Arsuaga, J.L., Carbonell, E. \& Bermúdez de Castro, J.M. 2003. The Sima de los Huesos date to beyond U/Th equilibrium (>350 kyr) and perhaps to 400-500 kyr: New radimoetric dates. Journal of Archaeological Science, 30, 275-280.

Bischoff, J.L., Williams, R.W., Rosenbauer, R.J., Aranburu, A., Arsuaga, J.L., García, N. \& Cuenca-Bescós, G. 2007. High-resolution U-series dates from the Sima de los Huesos hominids yields 600 kyrs: implications for the evolution of the early Neanderthal lineage. Journal of Archaeological Science, 34, 763-770.

Blumenschine, R. 1986. Carcass consumption sequences and archaeological distinction of scavenging and hunting. Journal Human Evolution, 15, 639-659.

Boaz, N.T., Ciochon, R.L., Xu, Q. \& Liu, J. 2004. Mapping and taphonomic analysis of the Homo erectus loci at Locality 1 Zhoukoudian, China. Journal of Human Evolution, 46, 519- 549.

Bocquet-Appel, J.P. \& Arsuaga, J.L. 1999. Age distribution of hominid samples at Atapuerca $(\mathrm{SH})$ and Krapina could indicate accumulation by catastrophe. Journal of Archaeological Science, 26, 327-338. 
Brain, C.K. 1958. The Transvaal ape-man bearing cave deposits. Transvaal Museum Memories, 11.

Brain, C.K. 1981. The Hunters or the Hunted? An Introduction to African Cave Taphonomy. The University of Chicago Press, Chicago.

Carbonell, E. \& Mosquera, M. 2006. The emergence of a symbolic behaviour: the sepulchral pit of Sima de los Huesos, Sierra de Atapuerca, Burgos, Spain. Human Palaeontology and Prehistory. Comptes Rendus Palevol, 5, 155-160.

Carbonell, E., Mosquera, M., Ollé, A., Rodríguez, X.P., Sala, R., Vergèés, J.M., Arsuaga, J.L. \& Bermúdez de Castro, J.M. 2003. Les premiers comportements funéraires auraient-ils pris place à Atapuerca, il y a 350000 ans? L'Anthropologie, 107, 1-14.

Carretero, J.M., Rodríguez, L., García-González, R., Arsuaga J.L., Gómez-Olivencia, A., Lorenzo, C., Bonmatí, A., Gracia, A., Martínez, I. \& Quam, R. 2012. Stature estimation from complete long bones in the Middle Pleistocene humans from the Sima de los Huesos, Sierra de Atapuerca (Spain). Journal of Human Evolution, 62, 242-255.

Díez, J.C. 1990. Estudio tafo-zooarqueológico del Pleistoceno Medio. Aplicación a la Sima de los Huesos. In: Sierra de Atapuerca. Burgos, I Jornadas Burgalesas de Historia. Introducción a la Historia de Burgos en la Edad Media. Monografias de Historia Castellano-Leonesa. Universidad de Burgos, 517-530.

Domínguez-Rodrigo, M. 1994. La formación de las acumulaciones óseas de macrofauna: revisión de los criterios de discernimiento de los agentes biológicos no antrópicos desde un enfoque ecológico. Zephyrvs, XLVI, 103-122.

Eaton, R.L. 1994. Interference competition among carnivores: A model for the evolution of social behaviour. Carnivores, 2, 9-16.

Fernández-Jalvo, Y. 2003. Tafonomía en la Sierra de Atapuerca, Burgos (España). Coloquios de Paleontología, 1, 147-162.

Fernández-Jalvo, Y. \& Andrews, P. 2001. Atapuerca, le conte de deux sites. L'Anthropologie, 105, 223-236.

Friscia, A., Spencer, L., Van Valkenburgh, B. \& Harris, J. 2008. Chronology and spatial distribution of large mammal bones in pit 91, Rancho la Brea. Palaios, 23, $35-42$.

García, N. 2003. Osos y otros carnívoros de la Sierra de Atapuerca. Fundación Oso Asturias, Oviedo.

García, N. \& Arsuaga, J.L. 1997. The carnivore remains from the Sima de los Huesos Middle Pleistocene site (Sierra de Atapuerca, Spain). Journal of Human Evolution, 33, 155-174.

García, N. \& Arsuaga, J.L. 2011. The Sima de los Huesos (Burgos, northern Spain): palaeoenvironment and habitats of Homo heidelbergensis during the Middle Pleistocene. Quaternary Science Reviews, 30, 1413-1419.

Haynes, G. 1980. Evidence of carnivor gnowing of Pleistocene and recent mammalian bones. Paleobiology, 6, 341-351.
Haynes, G. 1983. A guide for differentiating mammalian carnivore taxa responsible for gnaw damage to herbivore limb bones. Paleobiology, 9, 164-172.

Hill, A. 1979. Disarticulation and scattering of mammal skeletons. Paleobiology, 5, 261-274.

Howell, N. 1979. Demography of the Dobe !Kung. Academic Press, New York.

Hutson, J.M. 2008. Reanalysis and reinterpretation of the Kalkbank fauna accumulation, Limpopo province, South Africa. Journal of Taphonomy, 6, 399-428.

Jones, N., Smith, L., O’Connell, J., Hawkes, K. \& Kamuzora, C. 1992. Demography of the Hazda, an increasing and high density population of savanna foragers. American Journal of Physical Anthropology, 98, 159-181.

Kitchner, A. 1991. The Natural History of the Wild Cats. Christopher Helm, London.

Kurtén, B. 1958. Life and death of the Pleistocene cave bear. A study in palaeocology. Acta Zoologica Fennica, 95, 1-59.

Kurtén, B. 1976. The Cave Bear Story. Life and Death of a Vanished Animal. Columbia University Press, New York.

Martínez, I. \& Arsuaga, J.L. 1997. The temporal bones from Sima de los Huesos Middle Pleistocene site (Sierra de Atapuerca, Spain). A phylogenetic approach. Journal of Human Evolution, 33, 283-318.

Martínez, I., Quam, R.M., Rosa, M., Jarabo, P., Lorenzo, C., Bonmatí, A., Gómez-Olivencia, A., Gracia, A. \& Arsuaga, J.L. 2012. On the origin of language: the Atapuerca evidence. The 81st Annual Meeting of the American Association of Physical Anthropologists, Abstract Book, p. 111.

Martínez, I., Rosa, M., Quam, R., Jarabo, P., Lorenzo, C., Bonmatí, A., Gómez- Olivencia, A., Gracia, A. \& Arsuaga, J.L. 2013. Communicative capacities in Middle Pleistocene humans from the Sierra de Atapuerca in Spain. Quaternary International, 295, 94-101.

McHorse, B., Orcutt, J. \& Davis, E. 2012. The carnivoran fauna of Rancho La Brea: Average or aberrant? Palaeogeography, Palaeoclimatology, Palaeoecology, 329-330, 118-123.

Meyer, M., Fu, Q., Aximu-Petri, A., Glocke, I., Nickel, B., Arsuaga, J.L., Martínez, I., Gracia, A., Bermúdez de Castro, J.M., Carbonell, E. \& Paabo, S. 2014. A mitochondrial genome sequence of a hominin from Sima de los Huesos. Nature, 505, 403-406.

Morris, P. 1974. The mammal fauna of the ash-flow tuff blisters of Fantale, Ethiopia. Studies of Spelaelogy, 2, 233-237.

Ortega, A.I., Benito-Calvo, A., Pérez-González, A., MartínMerino, M.A., Pérez-Martínez, R., Parés, J. M., Aranburu, A., Arsuaga, J.L., Bermúdez de Castro, J. M. \& Carbonell, E. 2013. Evolution of multilevel caves in the Sierra de Atapuerca (Burgos, Spain) and its relation to human occupation. Geomorphology, 196, 122-137.

Palmqvist, P., Martínez-Navarro, B., Pérez-Claros, J., Torregrosa, V., Figueirido, B., Jiménez-Arenas, J.M., Espigares, P., Ros-Montoya, S. \& De Renzi, M. 2011. The giant hyena Pachycrocuta brevirostris: Modelling the bone-cracking behavior of an extinct carnivore. Quaternary International, 243, 61-79. 
Parés, J.M., Pérez-González, A., Weil, A.B. \& Arsuaga, J.L. 2000. On the age of the hominid fossils at Sima de los Huesos, Sierra de Atapuerca, Spain: paleomagnetic evidence. American Journal of Physical Anthropology, 111, 451-462.

Pérez-Pérez, A., Bermúdez de Castro, J.M. \& Arsuaga, J.L. 1999. Nonoclusal dental microwear analysis of 300.000 years-old Homo heidelbergensis teeth from Sima de los Huesos (Sierra de Atapuerca, Spain). American Journal of Physical Anthropology, 108, 433-457.

Rabadà, D. 1990. Nota preliminar sobre la tafonomía de la asociación fósil del Pleistoceno Medio en la Cova Gran (Serra del Montmell, Baix Penedès, NE de España). Acta Geológica Hispánica, 25, 4, 313-317.

Rabadà, D. 2001. Los homínidos de la Sima de los Huesos, ¿inhumaciones o accidentes? (Sierra de Atapuerca, Burgos, España). Batalleria, 10, 49-54.

Rabadà, D. 2007. La asociación fósil de la Sima de los Huesos: resultado de diversos procesos tafonómicos no antrópicos (Sierra de Atapuerca, Burgos, España). Batalleria, 13, 69-74.

Rayne, T., Clarke, R. \& Heaton, J. 2004. The context of Stw 573 , an early hominid skull and skeleton from Sterkfontein Member 2: taphonomy and paleoenvironment. Journal of Human Evolution, 46, 277-295.

Sala, N. 2012. Tafonomía de yacimientos kársticos de carnívoros en el Pleistoceno. Departamento de Paleontología. Universidad Complutense de Madrid, Madrid.

Sala, N., Algaba, M., Arsuaga, J.L., Aranburu, A. \& Pantoja, A. 2012. A Taphonomic study of the Búho and Zarzamora caves. Hyenas and humans in the Iberian Plateau (Segovia, Spain) during the Late Pleistocene. Journal of Taphonomy, 10, 477-497.

Sala, N. \& Arsuaga, J.L. 2013. Taphonomic studies with wild brown bears (Ursus arctos) in the mountains of northern Spain. Journal of Archaeological Science, 40, 1389-1396.

Sala, N., Arsuaga, J. L., Martínez, I. \& Gracia-Téllez, A. 2014. Carnivore activity in the Sima de los Huesos (Atapuerca, Spain) hominin sample. Quaternary Science Reviews, 97, 71-83.

Saladié, P., Huguet, R., Díez, C., Rodríguez-Hidalgo, A. \& Carbonell, E. 2013. Taphonomic modifications produced by modern brown bears (Ursus arctos). International Journal Osteoarchaeological, 23, 13-33.
Schaller, G. 1972. The Serengeti Lion. University of Chicago Press, Chicago.

Smith, D. I. 1975. The erosion of limestones on Mendip. In: Limestones and Caves of the Mendip Hills (eds. Smith, D.I. \& Drew, D.P.). David \& Charles, Newton Abbot, 135-170.

Sorriaux, P. 1982. Contribution à l'étude de la sédimentation en milieu karstique: Le systeme de Niaux-Lombrives-Sabart. Pyrenees Arigeoises. Thesis 3rd cycle, Université Paul Sabatier, Toulouse.

Spencer, L., Van Valkenburgh, B. \& Harris, J. 2003. Taphonomic analysis of large mammals recovered from the Pleistocene Rancho La Brea tar seeps. Paleobiology, 29, 561-575.

Stringer, C. 2012. The Status of Homo heidelbergensis (Schoetensack 1908). Evolutionary Anthropology, 21, 101-107.

Trinkaus, E. 1995. Neanderthal mortality patterns. Journal of Archaeological Science, 22, 121-142.

Ullrich, H. 1999. Life and death, mortuary practices and survival strategies in the Palaeolithic. In: Hominid Evolution. Lifestyles and Survival Strategies (ed. Ullrich, H.). Archaea, 543-562.

Vicente, J.L., Rodríguez, M. \& Palacios, J. 1999. Relaciones entre lobos y ciervos en la sierra de la Culebra. Quercus, 157, 10-15.

Vrba, E. 1980. The significance of bovid remains as indicators of environment and predation patterns. In: Fossils in the Making (eds. Behrensmeyer, A.K. \& Hill, A.P.). University Chicago Press, Chicago, 247-271.

Weigelt, J. 1989. Recent Vertebrate Carcasses and their Paleobiological Implications. University Chicago Press, Chicago.

White, J.A., McDonald, H.G., Anderson, E. \& Soiset, J.M. 1984. Lava blisters as carnivore traps. In: Contributions on Quaternary vertebrate paleontology: a volume in memorial to John E. Guilday. (eds. Genoways, H.H. \& Dawson, M.R.) Carnegie Museum of Natural History, 8, 241-256.

Yravedra, J., Lagos, L. \& Bárcena, F. 2011. A taphonomic study of wild wolf (Canis lupus) modification of horse bones in Northwestern Spain. Journal of Taphonomy, 9, $37-65$. 
